\title{
The Sensitivity of Non-U.S. Bank Stock Returns to Changes of U.S. Monetary Policy
}

\author{
Haiyan Yin ${ }^{1}$ and Jiawen Yang ${ }^{2}$
}

\begin{abstract}
This paper investigates the international spillover effect of U.S. monetary policy changes on non-U.S. bank stock returns. Our dataset covers 442 non-U.S. banks in 57 countries for 1994-2007. We find that there exists an inverse relationship between non-U.S. bank stock returns and unexpected changes in the U.S. federal funds rate target. Our study provides strong evidence that the sensitivity of non-U.S. bank stock returns varies with regard to the nature and context of monetary policy changes, bank-level characteristics, and country-level institutional factors. Our findings have important implications on international financial stability, trading and hedging strategies, and banking management and regulation.
\end{abstract}

JEL classification numbers: G21; G28; G14; E44; E58.

Keywords: International spillover; bank stock returns; Federal funds rate target; Bank Characteristics; Event study

\section{Introduction}

It is well documented that U.S. monetary policy has significant spillover effects over the global financial markets and the world economy. With comprehensive data of 49 countries, the recent study by Hausman and Wongswan (2011) shows that U.S. monetary policy announcement surprises have significant impact on foreign equity indexes, shortand long-term interest rates, and exchange rates. Bredin, Gavin and O'Reilly (2005) find that the volatility of the Irish stock market is affected by U.S. monetary shocks. Craine and Martin (2008) find that US monetary surprises affect Australian yields and equity returns. Kim and Nguyen (2009) provide comprehensive evidence on the spillover effects of the U.S. and EU monetary policy changes on the market returns and return volatilities of 12 stock markets in the Asia-Pacific region over 1999-2006. There are also studies that

\footnotetext{
${ }^{1}$ Judd Leighton School of Business and Economics, Indiana University South Bend, U.S.A.

${ }^{2}$ Department of International Business, The George Washington University, U.S.A.
} 
examine the spillover of macroeconomic shocks across countries. Elyasiani and Mansur (2003) find that banks in the United States, Japan, and Germany are sensitive to crosscountry macroeconomic shocks and the volatilities of bank stocks in the three countries are highly interdependent. The spillover effect of U.S. macroeconomic shocks to Japan and Germany is more pronounced than the other way around.

The banking sector plays an important role in financial intermediation and in transmitting monetary policy. How U.S. monetary policy affects the banking sector both inside and outside the United States has important implications for global financial stability. While there are a few studies of how U.S. monetary policies affect U.S. bank stock returns (see Madura and Schnusenberg, 2000; Yin, Yang and Handorf, 2010), research on the effect of U.S. monetary policy changes on bank returns outside the United States is still rare.

The purpose of this paper is to investigate the spillover effect of U.S. monetary policy changes on non-U.S. banks. Since 1987 when Alan Greenspan became Fed chairman, adjustment of the U.S. federal funds rate target has been the main monetary policy tool in the United States. We use changes in the federal funds rate target as the proxy for U.S. monetary policy movements. As such, we examine, through the event-study methodology, how changes in the U.S. federal funds rate target affect the stock returns of non-U.S. commercial banks for 1994-2007.

Our study yields several important findings. First, our empirical results show that unexpected upward (downward) adjustments in the federal funds rate target decrease (increase) stock returns of non-U.S. banks. This is consistent with the effect of U.S. monetary policy changes on the stock returns of U.S. banks. This also proves that the spillover effect of U.S. monetary policy on non-U.S. banks does exist.

Second, we test whether the responses of non-U.S. bank stocks to U.S. monetary policy changes vary in different contexts of such policy changes. These contexts include whether a change in the federal funds rate target is accompanied by a simultaneous change in the discount rate, whether the target change represents a policy reversal (for example, from rate increase to rate decrease), and the direction (positive changes vs. negative changes) of the change. We find that simultaneously adjusting the target rate and discount rate has no more pronounced effect on non-U.S. bank stocks than adjusting the federal funds rate target alone. We find that monetary shocks that change the monetary policy direction exert a much stronger influence on non-U.S. banks than other target changes. We also observe that non-U.S. banks are more sensitive to unexpected target decreases than increases.

Third, we examine whether bank characteristics matter in the spillover effect of U.S. monetary shocks on the non-U.S. banks. The bank characteristics that we investigate in this study include bank size, business activity mix, funding strategy, capital adequacy and insolvency risk. We find that unexpected changes in the federal funds rate target have more pronounced effect on large banks. Business activity mix, funding strategy, capital adequacy or insolvency risk do not have statistically significant impact on the spillover effect of U.S. monetary shocks when we control for other bank characteristics in the regression.

Finally, we investigate a series of macro and country-level institutional factors that may influence the international spillover effect of U.S. monetary policy change on non-U.S. bank returns. We find that banks located in countries with close economic ties with the United States, banks with heavy borrowings from the United States, and banks facing more stringent business activity restrictions are more sensitive to unexpected changes in the U.S. federal funds rate target. Conversely, U.S. monetary shocks exert a smaller 
effect on banks in countries with higher official supervision power, clear guidelines on geographical diversifications, and stringent capital requirement.

Our study contributes to the literature in several aspects. First, this study bridges a gap in the literature on the U.S. monetary policies' international spillover effect on non-U.S. banks. Second, we employ a broader and more updated database than previous studies. Existing studies on the international spillover effect of U.S. macroeconomic shocks cover only a few countries in the world or a specific region. Our dataset covers 442 banks in 57 countries. Third, we incorporate three sets of variables in our study: monetary policy variables, bank characteristics and country-level institutional variables. This allows us to examine the international spillover effect in a more comprehensive and systematic approach. To our knowledge, this is the first study of spillover effect of U.S. monetary policy on stocks of non-U.S. banks that incorporates country-level bank regulation variables.

\section{The Empirical Model and Hypotheses}

\subsection{The Basic Model}

The discounted cash flow model in finance asserts that the value of an asset equals the present value of expected future cash flows derived by the asset. Monetary policy affects asset values in two ways - through future cash flows and through the discount rate. An increase in the federal funds rate target represents a contractionary monetary policy, which leads to lower expected future cash flows. The increase in the discount factor for the expected future cash flows also decreases the assets' present value as the monetary policy tightens. The effect of a decrease in the federal funds rate target is vice versa. The inverse relationship between stock returns and changes in federal funds rate target is evidenced in the literature (see Bernanke and Kuttner (2005) for the general U.S. stock market, and Yin, Yang and Handorf (2010) for U.S. bank stock returns).

How U.S. monetary policy changes affect the financial markets in general and the bank stock returns in particular in other countries is of interest for global financial stability and international portfolio management. Elyasiani and Mansur (2003) argue that the development and wide application of telecommunication technology, globalization of business activities, and increased policy and regulatory coordination among the central governments are likely to strengthen the interdependence of banking sectors across countries. They find that the spillover effect of monetary shocks exists in the banking sector of the United States, Germany, and Japan. In this paper, we investigate the spillover effect of U.S. monetary policy on the stock returns of all non-U.S. banks whose data are available. We use bank-level daily stock returns as our dependent variable and the conventional event-study approach for the investigation. Our basic empirical model is specified as follows:

$\Delta P_{i t}=a+\gamma_{u} \cdot \Delta f f t a r_{u t}+\gamma_{\text {int }} \cdot \Delta f f t a r_{u t} \cdot \operatorname{char}+\varepsilon_{t}$

where $\Delta \mathrm{P}_{i t}$ is the one-day holding period return for bank $i$ from $t-1$ to $t ; \Delta \mathrm{fftar}_{u t}$ is the unexpected or the surprise component of the federal funds rate target changes; char represents factors that may influence the spillover effect, which include the different contexts in which the federal funds rate target was changed, bank characteristics, and country-level institutional variables. $\gamma_{u}$ measures the reaction of non-U.S. bank stock 
returns to the unexpected changes in the federal funds rate target and is expected to be negative; $\gamma_{\text {int }}$ measures the impact of a particular factor on the sensitivity of non-U.S. bank stock returns to U.S. monetary shocks. Since bank stocks are inversely related to target changes $\left(\gamma_{u<0)}, \gamma_{\text {int }}<0\right.$ implies that the higher the value of the factor char, the more responsive the bank stocks are to target changes. On the other hand, $\gamma_{\text {int }}>0$ indicates that non-U.S. bank equity sensitivity to target changes is negatively associated with the factor examined. $\varepsilon_{t}$ denotes the error term.

\subsection{U.S. Monetary Policy Spillover across Countries}

International financial market integration enhances the spillover of macroeconomic shocks and monetary policy changes across countries. ${ }^{3}$ Engle et al. (1990) and Elyasiani and Mansur (2003) find that stock prices interact across different country markets. Craine and Martin (2008) observe that international monetary policy surprises have inter-country repercussions in the financial markets between United States and Australia. The banking sector is special from other industries in that it plays a unique role in monetary policy transmission. As such, banks tend to be more sensitive to changes in monetary policy. It is commonly agreed that contagion occurs faster and spreads more broadly within the banking industry compared to other industries. ${ }^{4}$ Given international financial integration and the inverse relationship between stock prices and policy interest rate changes, we hypothesize that bank stocks in other countries are inversely affected by changes in the U.S. federal funds rate target.

\subsection{Spillover Effect and the Contexts of U.S. Monetary Policy Changes}

The Fed changes the federal funds rate target under different contexts. Sometimes a target change is accompanied by a simultaneous change in the discount rate, but other times the Fed adjusts the federal funds rate target without changing the discount rate. Does a joint change in the federal funds rate target and the discount rate contain more information or send a stronger signal to the market about the Fed's resolution to change monetary policy than a change in the federal funds rate target alone? Before the Fed changed its policy announcement procedure in February 1994, changes in the discount rate were an important signal of monetary policy to the market. Since February 1994, adjustments of the federal funds rate target have been released to the market immediately after such decisions are made, either at or outside the Federal Open Market Committee (FOMC) meetings. This procedure makes the federal funds rate target a more direct signal to the market than the discount rate. Yin, Yang and Handorf (2010) find supportive evidence that the discount rate has lost its information content since February 1994. Since the sample period of this study starts from 1994, we hypothesize that a joint change of target and discount rate makes no difference to the spillover effect of U.S. monetary policy

\footnotetext{
${ }^{3}$ Arshanapalli and Doukas (1993) and Karoiyi (1995) are two examples of studies on stock market integration and contagion across countries.

${ }^{4}$ See Kaufman (1994) for a review of the theory and evidence of bank contagion.
} 
adjustment on non-U.S. bank stock returns from a change of the federal funds rate target alone.

Changing from a contractionary policy to an expansionary policy or vice versa is termed as a policy reversal. Does a U.S. monetary policy reversal have a larger or stronger spillover than other changes? Evidence shows that the target adjustments that represent a new policy direction elicit a larger market response in the U.S. market. ${ }^{5}$ This can be explained by the fact that the Fed seldom reverses a monetary policy immediately after a new direction is started. The market tends to interpret the first target change in a new direction as the first of a series of target changes in the same direction, thus eliciting a more pronounced market reaction. We hypothesize that non-U.S. bank stocks are more sensitive to U.S. monetary policy reversals than other changes as well. That is, changes in the U.S. federal funds rate target have a larger or stronger spillover effect on non-U.S. bank stocks when such changes represent monetary policy reversals.

Do bank stocks react to policy interest rate increases in the same way as to policy interest rate decreases? That is, does the direction of policy changes (increase or decrease) matter in bank stock reactions? Madura and Schnusenberg (2000) find that decreases in policy interest rate elicit stronger responses of U.S. bank stocks than target rate increases. However, Yin, Yang and Handorf (2010) find no asymmetric responses of U.S. bank stocks to either positive or negative changes in the U.S. policy rate. In this paper we examine whether the direction of unexpected U.S. federal funds rate target changes makes a difference to the international spillover effect of U.S. monetary policy.

\subsection{Spillover Effect and Bank Characteristics}

Banks vary in size and have different characteristics. One important difference is that large money center banks tend to have foreign offices, engage in more international business and have a closer business connection with foreign countries. Historically, financial crises were aggravated by fast contagion across the largest banks (Elyasiani and Mansur, 2003). It is natural to argue that large banks are more sensitive to U.S. monetary shocks than small banks that are more locally oriented.

The traditional function of commercial banks is to absorb deposits and extend loans. Interest spread is their major source of income. Since the 1990s, there has been a global trend that banks diversify their income source through services in investment banking, insurance, credit cards and other non-traditional banking businesses. In this study, we examine whether such business diversification mitigates the sensitivity of non-U.S. banks to U.S. monetary policy changes.

While banks diversify their business operations, they diversify the funding sources as well. The money market has become an important source of funding for banks in addition to the traditional source of funds - deposits. However, money market funds typically are not covered by deposit insurance and have a highly elastic response to changes in market interest rates. As money markets become more integrated globally, we expect banks that rely more heavily on non-deposit money market funding in their liability structure to be more responsive to U.S. monetary shocks.

Bank capital serves as a buffer to absorb losses. Banks with higher capital ratios are more able to withstand market shocks. Madura and Schnusenburg (2000) find that well-

\footnotetext{
${ }^{5}$ See Thornton (1998) for the U.S. bond market, Bernanke and Kuttner (2005) for the U.S. stock market and Yin, Yang and Handorf (2010) for the U.S. banking sector.
} 
capitalized U.S. banks are less sensitive to monetary surprises. Similarly, we expect that non-U.S. banks with higher capital ratios are less sensitive to U.S. monetary shocks.

\subsection{Spillover Effect and Country-Level Institutional Factors}

As highlighted in Aggarwal and Goodell (2009), national characteristics are important determinants of financial intermediation. We argue that institutional factors differ across countries and such differences should influence the spillover effect of U.S. monetary policy changes in different countries. We consider the following country-level macro and institutional factors in this study: economic linkages with the United States, borrowing from the U.S., separation of commercial banking and other financial services, capital adequacy regulation, banking supervision and bank diversification guidelines.

Different countries have different economic and financial exposures to the United States. Countries that have closer economic linkages with the United States are more sensitive to macroeconomic shocks in the United States. Banks in such countries are, therefore, expected to have more pronounced reactions to changes in the federal funds rate target.

In investigating the relationship between bank globalization and monetary transmission, Cetorelli and Goldberg (2008) find that globalized banks activate internal capital markets between the parent banks and their overseas affiliates. When the Fed adjusts monetary policy, global banks respond to the resulting liquidity shock through an internal reallocation of funds, and ultimately their foreign lending will be affected. Correa and Murry (2010) also find evidence that during monetary tightening, U.S. banks significantly reduce their holdings of cross-border claims on foreign residents. Changes in the availability of funds caused by changes in the U.S. monetary policy affect the competitive environment of non-U.S. banks. We conjecture that banks in countries whose residents rely more on borrowing from the U.S. are affected more by U.S. monetary policy shocks. Whether or not commercial banks should be allowed to expand into financial services other than traditional banking has been at the center of debate on financial regulation. There are basically three types of regulatory framework regarding the business scope for banks: universal banking, thin firewall, and thick firewall. The German banking system represents universal banking in which banks are allowed to engage in investment and mortgage banking, mutual fund activity and holding stocks of commercial firms in addition to traditional banking businesses. The Japanese banking system provides for some product diversification by banks but maintains a separation between banking and securities businesses, and is characterized as a thin firewall system. The U.S. banking system, especially before the Glass-Steagall Act was repealed in 1999, on the other hand, was more restrictive and categorized as a thick firewall system (Elyasiani and Mansur, 2003). If non-banking activities bring forth diversification benefits, banks in countries that have more restrictions on bank activities are expected to be more sensitive to U.S. monetary shocks. However, this diversification effect on the spillover may be mitigated if banks' non-interest income is highly correlated with interest income. ${ }^{6}$

The importance of bank capital adequacy has been laid bare during the 2008 financial crisis. More stringent regulatory requirements for capital can help banks better withstand external shocks. Therefore, we expect banks in countries with stringent regulations on capital adequacy to be less affected by U.S. monetary shocks. Similarly, strong and

\footnotetext{
${ }^{6}$ Stiroh (2004) finds that noninterest income is very volatile and highly correlated with net interest income in the U.S. banking industry, suggesting few obvious diversification benefits for banks engaging in non-banking businesses.
} 
forceful banking supervision can help prevent banks from engaging in excessive risktaking activities and improve bank performance and stability. We argue that banks located in countries with higher banking supervisory power are less affected by U.S. monetary shocks. Regulation on banks' geographical asset diversification is another institutional factor that may affect the sensitivity of non-U.S. bank stocks to changes in the U.S. monetary policy. Diversifying the banks' businesses geographically may realize diversification effect which reduces the risk exposure of banks. Therefore, we propose that banks in countries with more regulatory emphasis on geographical asset diversification are less sensitive to U.S. monetary shocks.

\section{Data and Variables}

\subsection{The Dataset}

We compile a panel dataset that covers the period between February 1994 and December 2007. The starting point corresponds to the time when the FOMC's federal funds rate target became transparent. We end our sample with 2007 so as to exclude the period of economic turmoil from 2008 when the Federal Reserve shifted its monetary policy from adjusting the target rate to massive lending programs and asset purchases to ameliorate the credit crisis.

During the sample period, there are 53 changes in the federal funds rate target and 65 FOMC meetings in which the Fed decided not to change the target rate. The data for the target changes and FOMC meetings are compiled from the website of Federal Reserve Bank of New York, transcripts of FOMC meetings and the website of Federal Reserve Board of Governors. ${ }^{7}$ Among the 53 changes in the federal funds rate target, there are 10 target cuts at 50 basis points, 12 cuts at 25 basis points, 26 target increases at 25 basis points, 4 increases at 50 basis points and 1 increase at 75 basis points.

Following prior studies (Kuttner, 2001; Bernanke and Kuttner, 2005; Yin, Yang and Handorf, 2010), we use the 30-day federal funds futures data to isolate the unexpected component of target changes from the actual or announced target changes. The summary statistics of the actual, expected, and unexpected target rate changes are reported in Table 1. During the sample period, the surprise component of the target changes ranges from 43 to 15 basis points. The federal funds futures data that we have used to isolate the unexpected component of target changes are obtained from Datastream.

\footnotetext{
${ }^{7}$ http://www.ny.frb.org/markets/statistics//fedrate.html, http://www.federalreserve.gov/monetarypolicy/fomc_historical.htm, and http://www.federalreserve.gov/monetarypolicy/fomccalendars.htm, accessed December 29, 2009.
} 
Table 1: Summary statistics of target rate changes by year

\begin{tabular}{|c|c|c|c|c|c|c|c|c|c|c|c|c|c|}
\hline \multirow[t]{2}{*}{ Year } & & \multicolumn{4}{|c|}{$\begin{array}{l}\text { Actual target } \\
\text { change }\end{array}$} & \multicolumn{4}{|c|}{$\begin{array}{l}\text { Expected component of } \\
\text { target change }\end{array}$} & \multicolumn{4}{|c|}{$\begin{array}{l}\text { Unexpected component of } \\
\text { target change }\end{array}$} \\
\hline & $\mathrm{N}$ & Mean & Min & Max & $\mathrm{Sd}$ & Mean & Min & Max & $\mathrm{Sd}$ & Mean & Min & Max & $\mathrm{Sd}$ \\
\hline 1994 & 9 & 27.778 & 0 & 75 & 26.352 & 25.778 & 5 & 61 & 16.947 & 2 & -20 & 14 & 13.657 \\
\hline 1995 & 8 & 0 & -25 & 50 & 23.146 & -1.25 & -24 & 45 & 20.527 & 1.25 & -10 & 10 & 5.97 \\
\hline 1996 & 8 & -3.125 & -25 & 0 & 8.839 & 1 & -18 & 10 & 8.485 & -4.125 & -10 & 0 & 3.796 \\
\hline 1997 & 8 & 3.125 & 0 & 25 & 8.839 & 5.25 & 0 & 22 & 7.63 & -2.125 & -11 & 3 & 4.086 \\
\hline 1998 & 9 & -8.333 & -25 & 0 & 12.5 & -4.667 & -25 & 3 & 10.025 & -3.667 & -26 & 2 & 8.689 \\
\hline 1999 & 8 & 9.375 & 0 & 25 & 12.939 & 9.375 & -2 & 29 & 11.759 & 0 & -5 & 9 & 4.567 \\
\hline 2000 & 8 & 12.5 & 0 & 50 & 18.898 & 12.75 & -5 & 45 & 18.676 & -0.25 & -5 & 5 & 3.615 \\
\hline 2001 & 11 & -43.182 & -50 & -25 & 11.677 & -31.818 & -56 & -7 & 15.76 & -11.364 & -43 & 6 & 17.817 \\
\hline 2002 & 8 & -6.25 & -50 & 0 & 17.678 & -4.5 & -31 & 3 & 10.889 & -1.75 & -19 & 3 & 7.246 \\
\hline 2003 & 8 & -3.125 & -25 & 0 & 8.839 & -6.25 & -40 & 0 & 13.781 & 3.125 & 0 & 15 & 5.194 \\
\hline 2004 & 8 & 15.625 & 0 & 25 & 12.939 & 15.375 & 0 & 26 & 12.501 & 0.25 & -1 & 2 & 1.165 \\
\hline 2005 & 8 & 25 & 25 & 25 & 0 & 24.875 & 24 & 25 & 0.354 & 0.125 & 0 & 1 & 0.354 \\
\hline 2006 & 8 & 12.5 & 0 & 25 & 13.363 & 13.375 & 0 & 27 & 13.309 & -0.875 & -4 & 0 & 1.458 \\
\hline 2007 & 9 & -11.111 & -50 & 0 & 18.162 & -9.444 & -35 & 2 & 14.319 & -1.667 & -15 & 3 & 5.22 \\
\hline Total & 118 & 1.059 & -50 & 75 & 23.432 & 2.669 & -56 & 61 & 20.097 & -1.610 & -43 & 15 & 8.456 \\
\hline
\end{tabular}

Notes: We isolate the unexpected changes of rate target changes from the raw change with 30-day federal funds futures data. $\mathrm{N}$ represents a count of events, which includes the union of changes in the federal funds rate target and FOMC meetings. Mean, min, max and sd stand for average, minimum, maximum and standard deviation of target changes, respectively. Target change data are from the Federal Reserve Bank of New York http://www.ny.frb.org/markets/statistics/dlyrates/fedrate.html, accessed December 28, 2008. The data are in basis points except for count of events.

We use bank level data to gauge the spillover effect of U.S. monetary policy on non-U.S. banks. The bank stock price data are from Datastream and the bank characteristic data are gathered from Bankscope. Our dataset includes all publicly traded banks whose stock price data are available in Datastream and bank characteristics data in Bankscope for the period of 1994 to $2007 .{ }^{8}$ Our final dataset includes 442 different banks in 57 countries. Table 2 lists the countries and number of banks in each country. The number of banks in each country ranges from 1 to 97 and the appearance of each bank in the dataset ranges from 1 to 8 years.

${ }^{8}$ We eliminate banks that have inconsistent data. 
Table 2: Country and bank information of the sample

\begin{tabular}{llll}
\hline Country & No. of Banks & Country & No. of Banks \\
\hline Australia & 8 & Korea Rep. Of & 8 \\
Austria & 5 & Liechtenstein & 1 \\
Belgium & 4 & Sri Lanka & 6 \\
Bangladesh & 1 & Lithuania & 4 \\
Canada & 15 & Luxembourg & 2 \\
Switzerland & 10 & Morocco & 3 \\
China-People's Rep. & 7 & Mexico & 4 \\
Colombia & 2 & Malta & 3 \\
Cyprus & 3 & Mauritius & 2 \\
Czech Republic & 1 & Malaysia & 12 \\
Germany & 13 & Netherlands & 5 \\
Denmark & 12 & Norway & 1 \\
Ecuador & 2 & Pakistan & 5 \\
Spain & 9 & Peru & 3 \\
Finland & 3 & Philippines & 6 \\
France & 11 & Poland & 8 \\
United Kingdom & 10 & Portugal & 4 \\
Greece & 11 & Romania & 3 \\
Hong Kong & 11 & Russian Federation & 2 \\
Hungary & 1 & Singapore & 7 \\
Indonesia & 11 & Slovakia & 2 \\
India & 16 & Slovenia & 1 \\
Ireland & 4 & Sweden & 3 \\
Iceland & 2 & Thailand & 11 \\
Israel & 7 & Turkey & 13 \\
Italy & 12 & Taiwan & 13 \\
Japan & 97 & South Africa & 11 \\
Kazakhstan & 1 & Zimbabwe & 4 \\
Kenya & & & \\
\hline & & & \\
& 9 & & \\
\hline
\end{tabular}

\subsection{Measurement of Variables}

\subsubsection{Bank-level variables}

We measure the stock return of a bank as the percentage change of its stock price from the day before to the day of the announcement of a target change. The bank stock returns are adjusted for dividends if there are any. Due to time differences across countries, some stock exchanges (such as those in Asia) were closed when the Fed announced a monetary policy decision. In such cases, we measure the dividend-adjusted stock returns from the day of to the day after the Fed policy announcement. During the sample period, most of announcements were made immediately after the scheduled FOMC meetings in the afternoon. There are 5 cases when the FOMC adjusted the federal funds rate target in conference calls outside regular FOMC meetings. Upon examining these conference call transcripts, we find that some conferences adjourned at around 12:30 pm and some at 2:30 
pm. The lack of accurate information of the time at which the monetary policy changes are released to the public casts doubts on the validity of using the stock return of $t+1$ for some countries, especially those countries, such as Venezuela, that have a small time zone differences with the United States. To be safe, we exclude from our sample countries whose time zone differences with the United States are not zero but fewer than four hours. In addition to returns, we also measure various banking characteristics at the firm level. We use natural logarithm of a bank's total assets to gauge the bank's size. Following Demirguc-Kunt and Huizinga (2010) and Yin and Yang (2009), we define a bank's business activity mix with its share of fee income, which is defined as the share of noninterest income in the form of commissions, fees, and trading income in total operating income. The higher the share of fee income, the more the bank is diversified or involved in non-banking businesses. The funding source of banks is measured with the share of non-deposit short-term funding in total deposits \& short-term funding. Higher share of non-deposit funding represents more reliance on non-traditional funding sources, such as money market negotiable CDs, Eurodollar borrowings, and commercial papers, etc.

Bank capital adequacy is approximated with tier 1 capital ratio, which is the ratio of tier 1 capital to risk weighted assets and off-balance-sheet risks under Basel rules. Since tier 1 capital includes common stock and surplus, undivided profits and other important capital items, and the tier 1 capital ratio takes off-balance-sheet risks into consideration, it is a better measure of a bank's capital adequacy than a simple capital asset ratio which is based on balance-sheet items only.

As is widely used in the literature, $\mathrm{Z}$ scores are often used to proxy the insolvency risk of banks. The $\mathrm{Z}$ score is defined as $\frac{R O A+C A R}{S R O A}$ where ROA is the return on assets, CAR the capital assets ratio, and SROA the standard deviation of return on assets. We use $\ln (1+\mathrm{Z})$ in the regressions to smooth out higher values of $\mathrm{Z}$ scores.

\subsubsection{Country-level variables}

Our country-level variables include economic linkages with the United States, borrowing from the U.S., and bank regulation and supervision measures. A particular country's economic connection with the U.S. is measured as the country's total trade volume with the United States as a percentage of that country's GDP. Higher volume of trade represents more reliance on and a closer link with the U.S. economy. The trade data is retrieved from U.S. Department of Commerce. Borrowing from the U.S. is measured with a country's total loans from the U.S. by its residents as a percentage of its GDP. We obtain the loan data from the Federal Financial Institution Examination Council's (FFIEC) Country Exposure Lending Survey and Country Exposure Information Report. ${ }^{9}$ The data for GDP are from the World Development Indicators (WDI) of the World Bank.

We adopt four bank regulation variables as compiled and employed in Barth, Caprio and Levine (2004): restrictions on bank activities, stringency on capital regulation, official supervisory power, and geographical diversification. Restrictions on bank activities are measured with an index defined as restrictions on securities, insurance, and real estate activities plus restrictions on the banks owning and controlling nonfinancial firms. It takes values from 3 to 11 with higher values indicating more restrictions. Stringency on capital

\footnotetext{
${ }^{9}$ http://www.ffiec.gov/E16.htm, accessed November 8, 2010.
} 
regulation is measured with the capital regulatory index that ranges from 3 to 10 and higher values indicate greater stringency. Official supervisory power measures the extent to which official supervisory agencies have the authority to take specific actions to prevent and correct problems in the banking sector. It takes values from 5 to 14 with higher values indicating greater power. Geographical diversification is an index that measures whether regulations support geographical asset diversification. It ranges from 0 to 2, with higher values indicating more geographical diversification of bank assets in a country. Variable definitions and data sources are summarized in Table 3, summary statistics of the bank- and country-level variables are reported in Table 4 and the correlation matrix of bank- and country-level variables are displayed in Table 5.

Table 3: Variable definitions and data sources

\begin{tabular}{|c|c|c|}
\hline Variables & Description & Data Source \\
\hline $\begin{array}{l}\text { Bank stock } \\
\text { return }\end{array}$ & $\begin{array}{l}\text { One-day holding period return of a bank from the day before to the day of a } \\
\text { change in the federal funds rate target. }\end{array}$ & Datastream \\
\hline $\begin{array}{l}\text { Surprise } \\
\text { change }\end{array}$ & $\begin{array}{l}\text { Unexpected component of changes in federal funds rate target. It is isolated from } \\
\text { raw change with federal funds futures and used to approximate monetary shocks. }\end{array}$ & $\begin{array}{l}\text { Website of the } \\
\text { Fed and } \\
\text { Datastream }\end{array}$ \\
\hline $\begin{array}{l}\text { Joint change } \\
\text { dummy }\end{array}$ & $\begin{array}{l}\text { Binary dummy that equals } 1 \text { if the changes in federal funds rate target is } \\
\text { accompanied with a discount rate change }\end{array}$ & $\begin{array}{l}\text { Website of the } \\
\text { Fed }\end{array}$ \\
\hline $\begin{array}{l}\text { Policy } \\
\text { reversal } \\
\text { dummy }\end{array}$ & $\begin{array}{l}\text { Binary dummy that equals } 1 \text { if the changes in federal funds rate target represents a } \\
\text { policy reversal. }\end{array}$ & $\begin{array}{l}\text { Website of the } \\
\text { Fed }\end{array}$ \\
\hline $\begin{array}{l}\text { Direction } \\
\text { dummy }\end{array}$ & Binary dummy if the unexpected change in federal funds rate target is positive. & $\begin{array}{l}\text { Website of the } \\
\text { Fed }\end{array}$ \\
\hline Assets & Natural logarithm of total assets. It is a measure of bank size. & Bankscope \\
\hline $\begin{array}{l}\text { Non-interest } \\
\text { income share }\end{array}$ & $\begin{array}{l}\text { Other operating income as a share of total operating income. It is a proxy for } \\
\text { reliance on non-banking business }\end{array}$ & Bankscope \\
\hline $\begin{array}{l}\text { Non-deposit } \\
\text { funding } \\
\text { share }\end{array}$ & $\begin{array}{l}\text { Share of non-deposit short-term funding in total deposits \& short-term funding. It } \\
\text { is a measure of funding strategy. }\end{array}$ & Bankscope \\
\hline $\begin{array}{l}\text { Tier } 1 \text { capital } \\
\text { ratio }\end{array}$ & $\begin{array}{l}\text { Tier } 1 \text { capital as a percentage of risk-weighted assets and off-balance sheet risks } \\
\text { under Basel rules. It is a measure of capital adequacy. }\end{array}$ & Bankscope \\
\hline Z score & $\begin{array}{l}\text { Index of bank solvency constructed as }(\mathrm{ROA}+\mathrm{CAR}) / \mathrm{SROA} \text {, where ROA is return } \\
\text { on assets, CAR represents capital assets ratio and SROA stands for standard } \\
\text { deviation of return on assets. In the regression we use } \ln (1+\mathrm{Z}) \text { to smooth out large } \\
\text { values of } \mathrm{Z} \text {. }\end{array}$ & Bankscope \\
\hline $\begin{array}{l}\text { Trade with } \\
\text { the } \\
\text { U.S. }\end{array}$ & $\begin{array}{l}\text { Trade with U.S. as a percentage of GDP. It is a measure of economic exposure to } \\
\text { the U.S. }\end{array}$ & $\begin{array}{l}\text { Department of } \\
\text { Commerce; } \\
\text { WDI }\end{array}$ \\
\hline $\begin{array}{l}\text { Borrowing } \\
\text { from } \\
\text { the U.S. }\end{array}$ & Resident's borrowing from U.S. banks as a percentage of GDP. & FFIEC; WDI \\
\hline Restrict & Index of regulatory restrictions on bank activities & $\begin{array}{l}\text { Barth et al. } \\
(2004)\end{array}$ \\
\hline Capital & Index of regulatory stringency on capital adequacy & $\begin{array}{l}\text { Barth et al. } \\
(2004)\end{array}$ \\
\hline $\begin{array}{l}\text { Official } \\
\text { power }\end{array}$ & index of power of commercial bank supervisory agency & $\begin{array}{l}\text { Barth et al. } \\
(2004)\end{array}$ \\
\hline $\begin{array}{l}\text { Diversificati } \\
\text { on }\end{array}$ & index of geographical diversification guidelines imposed on banks & $\begin{array}{l}\text { Barth et al. } \\
(2004)\end{array}$ \\
\hline
\end{tabular}

Notes: Due to time zone differences, we use the one-day holding period return from the day of to the day after the change announcement for banks in countries whose stock markets are closed when an announcement of a U.S. monetary policy change was made. 
Table 4: Summary statistics of bank- and country-level variables

\begin{tabular}{llllll}
\hline Variable & N & Mean & Sd & Min & Max \\
\hline Assets & 442 & 23.256 & 2.090 & 17.858 & 28.080 \\
Non-interest income share & 434 & 0.416 & 0.195 & 0.059 & 0.993 \\
Non-deposit funding share & 438 & 0.059 & 0.115 & 0 & 0.846 \\
Tier 1 capital ratio & 323 & 10.484 & 6.429 & 3.225 & 79.200 \\
Z score & 288 & 2.582 & 0.882 & 0.272 & 4.733 \\
Trade with the U.S. & 175 & 0.113 & 0.127 & 0.010 & 0.563 \\
Borrowing from the U.S. & 234 & 2.112 & 4.305 & 0.005 & 54.125 \\
Restrict & 55 & 7.127 & 1.915 & 3 & 10 \\
Capital & 53 & 6.283 & 1.780 & 3 & 10 \\
Official power & 53 & 10.585 & 2.598 & 5 & 14 \\
Diversification & 55 & 1.491 & 0.540 & 0 & 2 \\
\hline
\end{tabular}

Notes: This table reports the summary statistics of the bank- and country-level variables. $\mathrm{N}$ represents number of observations. Mean, min, max and Sd stand for average, minimum, maximum and standard deviation, respectively. The bank level data are based on the cross-sectional data of 442 banks and obtained from Bankscope. Trade with the U.S. data are compiled from the website of the Department of Commerce and the borrowing from the U.S. data are obtained from FFIEC country exposure report. The GDP data used to calculate trade as a percentage of GDP and borrowing from the U.S. as a percentage of GDP are from World Development Indicators (WDI) of the World Bank. The bank regulation data including restrict, capital, official power and diversification are from Barth et al. (2004). The statistics for trade with the U.S. and borrowing from the U.S. are based on panel data and that for other country-level variables are calculated on crosssectional data.

Table 5: Correlation matrix of bank-level variables and country-level variables

\begin{tabular}{lllllll}
\hline Panel A: Bank-level variables & & & & & \\
& Assets & $\begin{array}{l}\text { Non- } \\
\text { interest } \\
\text { income } \\
\text { share }\end{array}$ & $\begin{array}{l}\text { Non- } \\
\text { deposit } \\
\text { funding } \\
\text { share }\end{array}$ & $\begin{array}{l}\text { Tier } \\
\text { capital } \\
\text { ratio }\end{array} \quad$ Z score \\
\hline Assets & 1 & & & & & \\
Non-interest income share & -0.1162 & 1 & & & & \\
& 0.0154 & & & & & \\
Non-deposit funding share & 0.1233 & 0.4476 & 1 & & & \\
& 0.0098 & 0 & & & & \\
Tier 1 capital ratio & -0.3832 & 0.2319 & -0.0237 & 1 & \\
& 0 & 0 & 0.6717 & & \\
Z score & 0.0542 & -0.0213 & 0.0587 & 0.0703 & 1 \\
& 0.3593 & 0.7221 & 0.3211 & 0.3038 & \\
\hline
\end{tabular}


Panel B: Country-level variables

\begin{tabular}{|c|c|c|c|c|c|c|}
\hline & $\begin{array}{l}\text { Trade } \\
\text { with the } \\
\text { U.S. }\end{array}$ & $\begin{array}{l}\text { Borrowing } \\
\text { from the } \\
\text { U.S. }\end{array}$ & Restrict & Capital & $\begin{array}{l}\text { Official } \\
\text { power }\end{array}$ & Diversification \\
\hline Trade with the U.S. & 1 & & & & & \\
\hline Borrowing from the U.S. & $\begin{array}{l}0.2914 \\
0\end{array}$ & 1 & & & & \\
\hline Restrict & $\begin{array}{l}-0.3249 \\
0\end{array}$ & $\begin{array}{l}-0.4236 \\
0\end{array}$ & 1 & & & \\
\hline Capital & $\begin{array}{l}-0.3281 \\
0\end{array}$ & $\begin{array}{l}0.0585 \\
0\end{array}$ & $\begin{array}{l}0.0117 \\
0.1265\end{array}$ & 1 & & \\
\hline Official power & $\begin{array}{l}-0.0936 \\
0\end{array}$ & $\begin{array}{l}-0.046 \\
0\end{array}$ & $\begin{array}{l}0.0942 \\
0\end{array}$ & $\begin{array}{l}0.0585 \\
0\end{array}$ & 1 & \\
\hline Diversification & $\begin{array}{l}0.1068 \\
0\end{array}$ & $\begin{array}{l}-0.0867 \\
0\end{array}$ & $\begin{array}{l}0.0102 \\
0.18\end{array}$ & $\begin{array}{l}0.085 \\
0\end{array}$ & $\begin{array}{l}0.248 \\
0\end{array}$ & 1 \\
\hline
\end{tabular}

Notes: this table reports the correlation matrix of bank- and country-level variables. Data in Italic shows p value.

\section{Results and Discussions}

\subsection{International Spillover Effect and the Contexts of Monetary Policy Changes}

Table 6 reports the estimates of the spillover effects of changes in the U.S. federal funds rate target on bank stocks of other countries. Column (1) confirms that there is an inverse relationship between bank stock returns and unexpected target changes. This evidence is consistent with what is found in the current literature on the effects of U.S. monetary policy changes on U.S. bank stocks. The statistically insignificant coefficient in column (2) supports our hypothesis that a joint change in the federal funds rate target and the discount rate does not have different spillover effects on non-U.S. banks from that of a change in the federal funds rate target change alone. This is consistent with the finding in Yin, Yang and Handorf (2010) that, under the current monetary policy regime since February 1994, a simultaneous change in the discount rate renders no additional information to a change in the federal funds rate target in conveying the U.S. monetary policy to the market. 
Table 6: Spillover effect and the contexts of monetary policy changes

\begin{tabular}{llllll}
\hline & $(1)$ & $(2)$ & $(3)$ & $(4)$ & $(5)$ \\
\hline Surprise change & $-0.00839 * * *$ & -0.00863 & -0.00016 & $-0.01327 * * *$ & -0.01756 \\
& $(0.00243)$ & $(0.01296)$ & $(0.00282)$ & $(0.00321)$ & $(0.01576)$ \\
Surprise change X & & & & & \\
Joint change dummy & & 0.00025 & & & 0.01380 \\
& $(0.01322)$ & & & $(0.01544)$ \\
Policy reversal dummy & & & $-0.03084^{* * *}$ & & $-0.02955^{* * *}$ \\
& & & $(0.00538)$ & & $(0.00609)$ \\
Direction dummy & & & $0.03009 * *$ & $0.02173^{*}$ \\
& & & & $(0.01181)$ & $(0.01260)$ \\
N & 18108 & 18108 & 18108 & 9033 & 9033 \\
R-sq & 0.001 & 0.001 & 0.002 & 0.002 & 0.005 \\
\hline
\end{tabular}

Notes: This table presents the spillover effect of the changes in federal funds rate target and how the spillover effect is dependent on the contexts under which the target changes are made. The dependent variable is the one-day holding-period return of bank stocks from the day before to the day of policy change announcement. We use the one-day holding period return from the day of to the day after the change announcement for banks in countries whose stock markets are closed when an announcement of a U.S. monetary policy change was made to account for time zone difference. The full sample includes 53 target changes and 65 FOMC meetings when the Fed decided not to change the federal funds rate target for the period 1994-2007. The variable definitions and data sources are reported in Table 3. Standard errors are reported in parentheses. *, ** and *** denote significance at $10 \%, 5 \%$ and $1 \%$, respectively.

Column (3) of Table 6 provides strong evidence that U.S. monetary policy reversal elicits a larger effect on non-U.S. banks than a target change that extends the previous monetary policy direction. This is consistent with the existing literature for U.S. bond market (Thornton, 1998), the general U.S. stock market (Bernankee and Kuttner, 2005), and U.S. bank stocks (Yin, Yang and Handorf, 2010).

The positive and significant coefficient in Column (4) of Table 6 shows that non-U.S. banks are less responsive to positive than to negative federal funds rate target changes. This is consistent with the finding of Madura and Schnusenberg (2000) that the sensitivity of U.S. bank stock returns to the federal funds rate target changes is ten times stronger for reductions than for increases in the rate target. Our result indicates that monetary easing in the U.S. (as represented by a cut in the federal funds rate target) exerts a larger impact on non-U.S. banks than a tightening monetary shock. The results reported in Columns (2)-(4) are robust as shown in Column (5) of Table 6 where we control for other contexts in which the federal funds rate target changes are made.

\subsection{Spillover Effect and Bank Characteristics}

Table 7 presents how the international spillover effect of U.S. monetary shocks is related to bank characteristics. Column (1) of Table 7 shows that large banks are more responsive to U.S. monetary shocks. This supports our argument that large banks tend to be more engaged in international business and better integrated with U.S. markets and, therefore 
are more inversely affected by unexpected target rate changes. This relationship still holds when we control for other bank characteristics, as is shown in Column (6). Column (2) of Table 7 shows that non-U.S. banks that rely more on non-traditional banking business are more sensitive to U.S. monetary policy changes. However, this relationship disappears when bank size and other bank characteristics are controlled for (Column (6)). It appears that non-U.S. banks using more non-deposit funding sources are more sensitive to U.S. federal funds rate target changes, as shown in Column (3), but this relationship becomes insignificant in Column (6) when other bank characteristics are controlled for. This result is weaker than the finding that U.S. banks replying more on non-deposit short-term funds are statistically more responsive to target rate changes (Yin and Yang, 2009). One plausible explanation is that changes in the federal funds rate target affect U.S. and nonU.S. banks through different channels. The federal funds market is an important alternative source of funds for U.S. banks but not for non-U.S. banks. The adjustment in the federal funds rate target directly influences the funding cost of U.S. banks, but the non-deposit funding for non-U.S. banks come from many different sources than the federal funds market.

Table 7: Spillover effect and bank characteristics

\begin{tabular}{|c|c|c|c|c|c|c|}
\hline & (1) & (2) & (3) & (4) & (5) & (6) \\
\hline Surprise change & $\begin{array}{l}0.14327 * * * \\
(0.02997)\end{array}$ & $\begin{array}{l}0.00420 \\
(0.00554)\end{array}$ & $\begin{array}{l}-0.00621 * * \\
(0.00272)\end{array}$ & $\begin{array}{l}-0.02276 \text { **** } \\
(0.00595)\end{array}$ & $\begin{array}{l}-0.01376^{*} \\
(0.00764)\end{array}$ & $\begin{array}{l}0.08437 * \\
(0.04976)\end{array}$ \\
\hline \multicolumn{7}{|l|}{ Surprise change $\mathrm{X}$} \\
\hline Assets & $\begin{array}{l}-0.00663 * * * \\
(0.00131)\end{array}$ & & & & & $\begin{array}{l}-0.00431 * * \\
(0.00197)\end{array}$ \\
\hline $\begin{array}{l}\text { Non-interest income } \\
\text { share }\end{array}$ & & $\begin{array}{l}-0.03280^{* *} \\
(0.01294)\end{array}$ & & & & $\begin{array}{l}-0.00388 \\
(0.02270)\end{array}$ \\
\hline $\begin{array}{l}\text { Non-deposit funding } \\
\text { share }\end{array}$ & & & $\begin{array}{l}-0.03902 * \\
(0.02190)\end{array}$ & & & $\begin{array}{l}-0.00669 \\
(0.04535)\end{array}$ \\
\hline Tier 1 capital ratio & & & & $\begin{array}{l}0.00170 * * * \\
(0.00054)\end{array}$ & & $\begin{array}{l}0.00026 \\
(0.00067)\end{array}$ \\
\hline $\mathrm{Z}$ score & & & & & $\begin{array}{l}0.00188 \\
(0.00279)\end{array}$ & $\begin{array}{l}0.00321 \\
(0.00309)\end{array}$ \\
\hline $\mathrm{N}$ & 18108 & 17836 & 18028 & 14175 & 15102 & 12102 \\
\hline $\mathrm{R}-\mathrm{sq}$ & 0.002 & 0.001 & 0.001 & 0.001 & 0.001 & 0.001 \\
\hline
\end{tabular}

Notes: This table presents the spillover effect of U.S. monetary shocks on non-US banks and shows how the spillover effect is conditional on bank characteristics. The dependent variable is the one-day holding-period return of bank stocks from the day before to the day of policy change announcement. We use the one-day holding period return from the day of to the day after the change announcement for banks in countries whose stock markets are closed when an announcement of a U.S. monetary policy change was made to account for time zone difference. The variable definitions and data sources are reported in Table 3. Standard errors are reported in parentheses. *, ** and $* * *$ denote significance at $10 \%, 5 \%$ and $1 \%$, respectively.

The effects of capital adequacy and insolvency risk on the international spillover are reported in Columns (4) and (5) of Table 7 respectively. There is strong evidence that non-U.S. banks that are well capitalized are less sensitive to U.S. monetary policy shocks. 
However, this finding is not robust as the statistical significance disappears in Column (6) where other bank characteristics are included in the estimation. $\mathrm{Z}$ score measures the insolvency risk of banks. Banks with less insolvency risk or higher $\mathrm{Z}$ scores are supposed to be less sensitive to U.S. monetary shocks. However, we find no statistically significant evidence for this expected result, as shown in Columns (5) and (6) of Table 7, although the signs of the coefficient are consistent with our hypothesis.

\subsection{Spillover Effect and Country-Level Institutional Factors}

Table 8 reports our estimates of how country-level factors affect the sensitivity of stock returns of non-U.S. banks to federal funds rate target changes. The negative coefficients for the interaction term in Columns (1) and (7) of Table 8 provide strong evidence that U.S. monetary policy surprises have larger spillover effect on banks in countries that have closer economic linkages with the United States. Column (2) shows that more borrowing from the U.S. is related to higher sensitivity, which is consistent with our hypothesis that banks located in countries with high-level borrowing from the U.S. banks are more sensitive to the U.S. monetary shocks. However, this effect loses statistical significance when all country-level factors are included in the regression, as shown in Column (7) of Table 8.

Table 8: Spillover effect and country-level macro and institutional variables

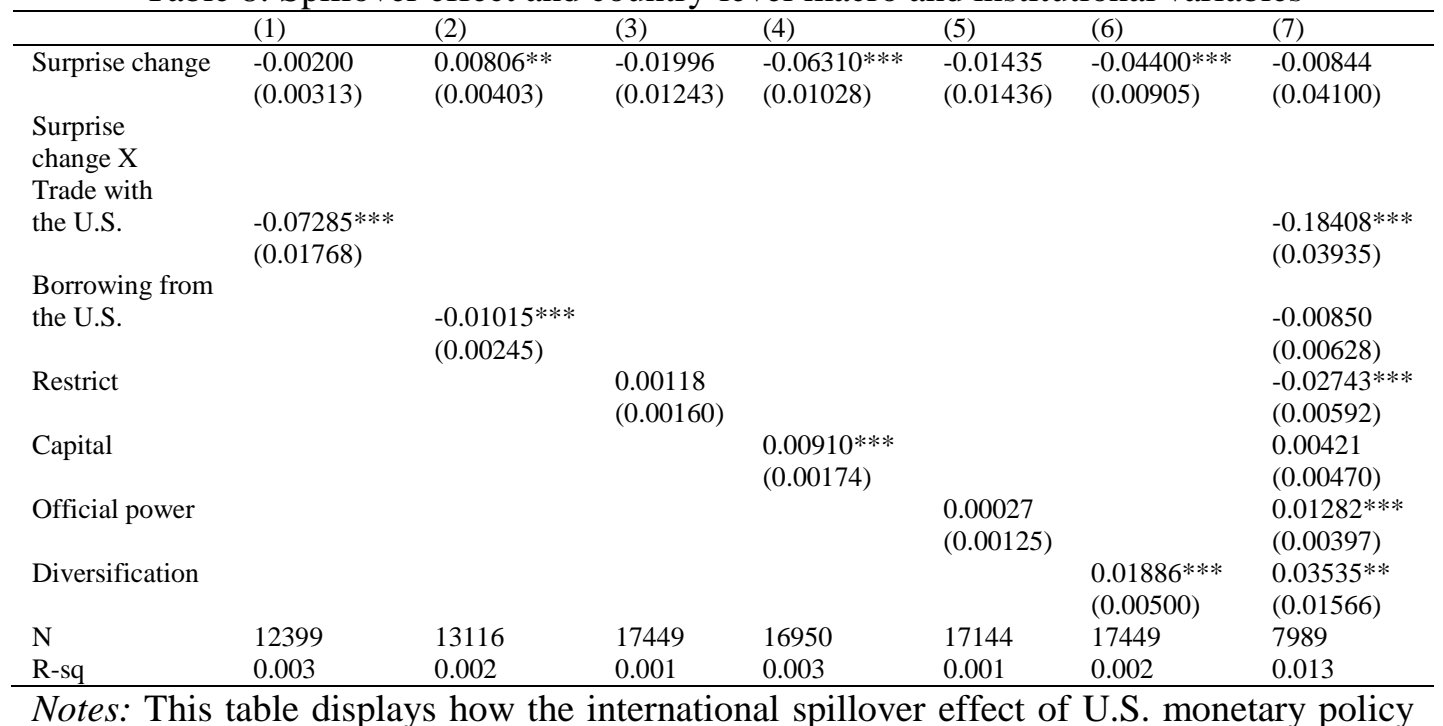
on bank stocks varies with banking regulations. The dependent variable is the one-day holding-period return of bank stocks from the day before to the day of policy change announcement. We use the one-day holding period return from the day of to the day after the change announcement for banks in countries whose stock markets are closed when an announcement of a U.S. monetary policy change was made to account for time zone difference. The variable definitions and data sources are reported in table 3. Standard errors are reported in parentheses. ${ }^{*}, * *$ and $* * *$ denote significance at $10 \%, 5 \%$ and $1 \%$, respectively. 
Column (3) of Table 8 indicates that regulatory restrictions on bank business activities do not matter to the sensitivity of non-U.S. bank stock returns to U.S. monetary shocks. However, the estimated coefficient becomes significantly negative in the last column of Table 8 , suggesting that banks in a regime with stringent regulatory restrictions on bank activities are more sensitive to U.S. monetary shocks. In other words, less stringent business-activity restrictions are conducive to a more diversified business structure of banks and are less susceptible to U.S. monetary shocks. This result is consistent with the business diversification effect. The coefficient for the capital regulation factor is positive and statistically significant as shown in Column (4) of Table 8, indicating that more stringent capital requirement in a country makes the bank stock returns less responsive to U.S. monetary shocks. This result remains positive but less significant when all countrylevel variables are included in the regression, as shown in Column (7). This finding confirms our results in Columns (4) and (6) of Table 7, where banks with higher capital ratios are less susceptible to U.S. monetary shocks, but the statistical significance vanishes when other bank characteristics variables are controlled for. Columns (5) and (7) of Table 8 reports the test results for the hypothesis that higher official supervisory power helps monitor banks more effectively and ensures better bank performance and stability and, therefore, banks in this regime are less affected by U.S. monetary shocks. We find significant evidence in Column (7) but not in Column (5) of Table 8. The results of how regulations on geographical diversification affect the sensitivity of non-U.S. bank stock returns to U.S. monetary shocks are reported in Columns (6) and (7) of Table 8. We find strong evidence that regulations that allow banks to have more geographical diversification of assets help insulate banks from U.S. monetary shocks.

\section{Summary and Conclusions}

This paper investigates how U.S. monetary policy changes, as exemplified by changes in the federal funds rate target, affect the stock returns of non-U.S. banks. Through analyses of a comprehensive dataset of daily stock returns for 442 banks in 57 countries for the period 1994 to 2007, we find significant spillover effects of U.S. monetary policy shocks on the banking sector of other countries. Non-U.S. bank stock returns, like U.S. bank stock returns, are found to be inversely related to changes in the U.S. federal funds rate target. With one basis point unexpected increase (decrease) in federal funds rate target, non-U.S. bank stock returns decrease (increase) by 0.0084 percent on average.

The relationship between non-U.S. bank stock returns and the changes in the U.S. federal funds rate target is further examined in three different dimensions: (1) the contexts in which the U.S. federal funds rate target is adjusted; (2) bank characteristics; and (3) the country-level institutional settings for bank operations. For the contexts in which U.S. monetary policy has been conducted, we find that the policy reversals, or directional changes, in the U.S. federal funds rate target have the most significant spillover effect. We also observe that non-U.S. banks are more sensitive to unexpected target decreases than increases. By examining bank-level data, we find that the spillover effect increases with bank size, which supports the argument that large banks tend to be more involved in international business and thus are more affected by U.S. monetary shocks than smaller and locally oriented banks. When we control for other bank characteristics, we find no statistically significant evidence that bank business structure, funding sources, capital adequacy, or insolvency risk matters to the spillover effect of U.S. monetary shocks. 
For country-level macro and institutional factors, we find strong evidence that banks in countries that have a closer economic relationship with the U.S. or more stringent business activity restrictions are more sensitive to unexpected changes in the U.S. federal funds rate target. Conversely, U.S. monetary shocks exert a smaller effect on banks in countries with higher supervision power and guidelines allowing for geographical diversifications. We find evidence, albeit statistically insignificant, that banks located in countries with more borrowings from the U.S. are more sensitive to U.S. monetary shocks, and that banks in countries with stringent capital adequacy regulations are less affected by U.S. monetary shocks.

Our study is the first to investigate the spillover effect of U.S. monetary policy changes on the stock returns of non-U.S. banks. The comprehensive coverage of non-U.S. banks, the different contexts of policy adjustments, and the inclusion of bank characteristics and country-level institutional factors allow us to examine the international spillover effect of U.S. monetary policy in a more systematic approach. Our findings provide insights for the understanding of international transmission of monetary policy and international financial management.

ACKNOWLEDGEMENTS: This research is supported by a Faculty Research Grant of the Indiana University South Bend.

\section{References}

[1] J. Hausman and J. Wongswan, Global asset prices and FOMC announcements, Journal of International Money and Finance, 30(3), (2011), 547-571.

[2] D. Bredin, C. Gavin and G. O'Reilly, U.S. monetary policy announcements and Irish stock market volatility, Applied Financial Economics, 15(17), (2005), 12431250.

[3] R. Craine and V. L. Martin, International monetary policy surprise spillovers, Journal of International Economics, 75(1), (2008) 180-196.

[4] S. Kim and D. Q. T. Nguyen, The spillover effects of target interest rate news from the U.S. Fed and the European Central Bank on the Asia-Pacific stock markets, Journal of International Financial Markets, Institutions and Money, 19(3), (2009), 415-431.

[5] E. Elyasiani and I. Mansur, International spillover of risk and return among major banking institutions: A bivariate GARCH model, Journal of Accounting, Auditing \& Finance, 18(2), (2003), 303-330.

[6] J. Madura and O. Schnusenberg, Effect of Federal Reserve policies on bank equity returns, The Journal of Financial Research, 23(4), (2000), 421-447.

[7] H. Yin, J. Yang and W. C. Handorf, State dependency of bank stock reaction to Federal funds rate target changes, Journal of Financial Research, 33(3), (2010), 289-315.

[8] B. S. Bernanke and K. N. Kuttner, What explains the stock market's reaction to Federal Reserve policy? The Journal of Finance, 60(3), (2005), 1221-1257.

[9] B. Arshanapalli and J. Doukas, International stock market linkages: Evidence from the pre- and post-October 1987 period, Journal of Banking \& Finance, 17(1), (1993), 193-208. 
[10] A. G. Karolyi, A multivariate GARCH model of international transmission of stock returns and volatility: The case of the United States and Canada, Journal of Business and Economic Statistics, 13(1), (1995), 11-25.

[11] R. F. Engle, T. Ito and W. L. Lin, Meteor showers or heat waves? Heteroskedastic intra-day volatility in the foreign exchange market, Econometrica, 58(3), (1990), 525-542.

[12] G. G. Kaufman, Bank contagion: A review of the theory and evidence, Journal of Financial Services Research, 8(2), (1994), 123-150.

[13] R. Aggarwal and J. W. Goodell, Markets and institutions in financial intermediation: National characteristics as determinants. Journal of Banking \& Finance, 33(10), (2009), 1770-1780.

[14] N. Cetorelli and L. S. Goldberg,. Banking globalization, monetary transmission and the lending channel, NBER Working Paper, no. W14101, (2008).

[15] R. Correa and C. Murry, Is there a cross-border bank lending channel? Evidence from US banks' international exposure. Bank for International Settlements Communications CH-4002 Basel, Switzerland, (2010): 113.

[16] K. J. Stiroh, Diversification in banking: Is noninterest income the answer? Journal of Money, Credit, and Banking, 36(5), (2004), 853-882.

[17] K. N. Kuttner, Monetary policy surprises and interest rates: Evidence from the Fed Funds future market, Journal of Monetary Economics, 47(3), (2001), 523-544.

[18] A. Demirguc-Kunt and H. Huizinga, Bank activity and funding strategies: The impact on risk and returns, Journal of Financial Economics, 98(3), (2010), 626-650.

[19] H. Yin and J. Yang, Bank characteristics and stock reaction to Federal funds rate target changes, FMA annual conference, Reno, Nevada, (2009).

[20] J. R. Barth, G. Caprio and R. Levine, Bank supervision and regulation: what works best? Journal of Financial Intermediation, 13(2), (2004), 205-48.

[21] D. Thornton, Tests of the market's reaction to Federal Funds rate target changes, Federal Reserve Bank of St. Louis Review, 80, (1998), 25-36. 